Running heads:

C. M. Dang et al.

Audit Quality for US-listed Chinese companies

International Journal of Auditing

Int. J. Audit. XX: 000-000 (XXXX)

\title{
Audit Quality for US-listed Chinese Companies
}

Chien Minh Dang, ${ }^{1}$ Neil Fargher ${ }^{1}$ and Gladys Lee ${ }^{2}$

${ }^{1}$ The Australian National University

${ }^{2}$ University of Melbourne

PCAOB Staff Audit Practice Alert No. 6 raised concerns regarding the quality of audit reports on financial statements filed by issuers with substantially all of their operations outside of the US. An area of specific concern is the audit of companies with operations predominantly based in mainland China. Using a sample of Chinese companies listed in the US, we examine whether measures of audit quality are affected by the location of the auditor. We find some evidence of higher levels of discretionary accruals when a USlisted Chinese firm is audited by a small US auditor.

Key words:

Correspondence to: Neil Fargher, Research School of Accounting, The Australian National University, Canberra ACT 0200, Australia. Email: neil.fargher@anu.edu.au

\section{INTRODUCTION}

PCAOB Staff Audit Practice Alert No. 6 (PCAOB, 2010) draws attention to the increasing number of audit firms located in the United States (US) issuing audit reports on financial statements of firms whose business operations are substantially located outside of the US.

This is the author manuscript accepted for publication and has undergone full peer review but has not been through the copyediting, typesetting, pagination and proofreading process, which may lead to differences between this version and the Version of Record. Please cite this article as doi: 10.1111/ijau.12085 
While not inherently inappropriate, the concern is whether such audits provide an appropriate level of audit quality. At issue is the extent of work conducted by local auditors and consultants other than the principal auditor when auditing international businesses, and the supervision of the work conducted (PCAOB, 2010). ${ }^{1}$

An area of particular concern is the audit quality for the audit of Chinese companies listed in the US (e.g. PCAOB, 2010, 2011; SEC, 2011). ${ }^{2}$ The concerns noted by the PCAOB include the mismatch in location between auditor and client, quality control over the audit, an over-reliance on other auditors and consultants engaged from outside the principal audit firm, ${ }^{3}$ the failure to adequately supervise, the failure to evaluate source documents, and the failure to communicate effectively with clients in the Chinese language. ${ }^{4}$

This study examines audit quality for audit firms located in the US issuing audit reports on financial statements of firms whose business operations are substantially located in mainland China. Carcello et al. (2014) argue that the PCAOB inspections of small US audit firms' Chinese clients were largely ineffective in many instances because audit work was outsourced to Chinese firms, leaving PCAOB inspectors with no ability to assess the quality of audit work undertaken in mainland China. We are unaware of any research which provides evidence on the issue of systematic low audit quality for audits conducted by small US-based audit firms auditing Chinese companies.

We examine audit quality for a sample of firms based in mainland China and listed on US stock exchanges during the period 2000 to 2014. We find evidence of higher levels of discretionary accruals when a US-listed Chinese firm is audited by a small US principal auditor compared to small auditors located in Hong Kong. We consider two other proxies for 
audit quality - restatements and allegations of fraud. We find that firms experience a higher likelihood of restatements when a US-listed Chinese firm is audited by a small US principal auditor, but this result is only significant at the alpha level of $10 \%$ (two tailed). Our comparisons highlight the nature of this audit market where small Chinese firms listed on US exchanges need a PCAOB registered auditor, and many such firms select smaller auditors located in the US, rather than auditors located in Hong Kong or mainland China with implications for the quality of audit provided.

This research makes two contributions. First, we provide evidence on an issue of specific interest to the PCAOB regarding the audit quality provided by auditors of firms with operations primarily in China but listed on US exchanges. Second, the results have broader implications for regulators in China and other transitional economies, foremost of which is that institutional structures need to consider the ability of audit firms to obtain adequately supervised audits of companies listed on foreign exchanges.

\section{BACKGROUND}

Considerable attention has been drawn to the reporting practices of China-based firms listed on the US stock exchanges (Lee, Li \& Zhang, 2015; Ang, Jiang \& Wu, 2016). ${ }^{5}$ The SEC suspended trading on more than 20 Chinese firms in 2011 (Lee et al., 2015). ${ }^{6}$ Auditors of some of these firms have been criticised for their failure to comply with professional standards in auditing financial statements and reporting financial misstatements (PCAOB, 2011). The lack of adequate audit quality has also been raised with respect to several USlisted Chinese firms investigated for accounting frauds (SEC, 2012). 
For Chinese firms seeking to raise international capital by listing on the US markets, the use of a Big 4 auditor was the accepted approach for companies and this led to the domination of Big 4 auditors in this audit market (Gillis, 2011). However, as smaller and riskier clients have listed in the US, these smaller clients have tended to rely on auditors other than the Big 4 auditors. For listing in the US the auditor must be registered with the PCAOB. As a result, many Chinese firms listing in the US have selected smaller auditors, primarily US accounting firms. Arguably the need for a US-registered auditor has led to more international businesses using small US audit firms willing to issue audit reports on financial statements of firms whose business operations are located outside of the US - the specific concern raised in PCAOB Staff Audit Practice Alert No. 6 (PCAOB, 2010). Some prior evidence on audit quality is available for these firms. Carcello et al. (2014) find that USlisted Chinese companies were more likely than companies from other countries to not hire high quality annually-inspected US audit firms.

\section{PRIOR LITERATURE AND RESEARCH QUESTION}

Audit quality would typically be expected to be of higher quality under a stronger regulatory and legal regime such as the US (Choi et al., 2008; Hung, Ma \& Wang, 2014). This would suggest that, all else equal, a US audit firm fulfilling the role of principal auditor would have a higher audit quality relative to an auditor in a weaker legal regime. ${ }^{7}$ From this perspective, a US audit firm fulfilling the role of principal auditor would be expected to have a higher audit quality relative to an auditor in mainland China or Hong Kong. 
On the other hand, proximity between auditor and client has been found to have a positive impact on audit quality by increasing the auditor's ability to gather client-specific information (Choi et al., 2012; Hanes, 2013). ${ }^{8}$ From this perspective, a US audit firm fulfilling the role of principal auditor for a client in mainland China would have a poorer audit quality relative to an auditor that is more proximate to the client. For larger US audit firms, we expect that issues relating to proximity would be less of a concern to audit quality because such firms have global networks and thus have a better ability to supervise audits at a distance (Carson, 2009). In contrast, a small US audit firm with a lack of proximity to the client that fails to provide adequate supervision of local auditors and consultants used on the audit, would have a lower audit quality than auditors more proximate to the client. ${ }^{9}$

Given the potentially contrasting effects on net audit quality from differing regulatory regimes and auditor legal liability, distance between auditor and client, and the ability of auditors of varying size to manage audits conducted at a distance, we specifically consider the following research question regarding the net audit quality observed:

RQ: For audits of Chinese companies listed on exchanges in the US, is the use of a small principal auditor with an engagement office in the US associated with lower audit quality relative to alternate choices of principal auditor?

\section{RESEARCH METHODOLOGY}

\section{Sample}

The sample consists of firms with business operations based in mainland China that are listed on the primary US stock exchanges and the principal auditor was listed as located in 
mainland China, Hong Kong or the US. ${ }^{10}$ The sample selection criteria are summarised in Table 1. We initially search the Audit Analytics database for the location of the client firm's corporate headquarters (Audit Analytics field 'BUS_STATE_COUNTRY') as mainland China. This item represents the client firm's headquarters location registered with the SEC. We also require auditor name ('AUDITOR_NAME'), auditor location ('AUDITOR_COUNTRY'), and incorporation location ('INC_STATE_NAME'). This initial search provides a sample of 3,960 firm-year observations over the years 2000 to 2014. We drop 780 firm-year observations due to missing audit fee data, primarily from the early years of the sample period. We exclude 146 firm-year observations that are not audited by an auditor located in the US, mainland China or Hong Kong. The sample is further reduced by 1,006 firm-year observations due to missing financial data from the Compustat database. There is only one observation recorded as a small Chinese audit firm; we exclude this observation. ${ }^{11}$ The final sample consists of 2,027 firm-year observations of 355 Chinese firms listed on the major US stock exchanges over the years 2000 to $2014 .^{12}$

In examining the audit quality for audits of US-listed Chinese companies we consider three measures of audit quality: discretionary accruals, probability of a restatement, and propensity of experiencing an allegation of financial misconduct. ${ }^{13}$

\section{Discretionary accruals as the proxy for audit quality}

Our measure of discretionary accruals is estimated from the cross-sectional modified Jones model (DeFond \& Subramanyam, 1998; Bartov, Gul \& Tsui, 2000). ${ }^{14}$ We estimate the following cross-sectional modified Jones model for each two-digit SIC industry and year: 


$$
\frac{A C C R_{j, t}}{T A_{j, t-1}}=\beta_{1} \frac{1}{T A_{j, t-1}}+\beta_{2} \frac{\left(\Delta R E V_{j, t}-\Delta R E C_{j, t}\right)}{T A_{j, t-1}}+\beta_{3} \frac{P P E_{j, t}}{T A_{j, t-1}}+\varepsilon_{j, t}
$$

where

$A C C R_{j, t}=$ total accruals for firm $j$ in year $t$, calculated as income before extraordinary items (Compustat item 18) minus cash flow from operating activities $=$ (Compustat item 308).

$T A_{j, t-1}=$ lagged total assets (Compustat item 6), or total asset for firm $j$ in year $t^{-1}$.

$\Delta R E V_{j, t}=$ change in net operating revenue (Compustat item 12) for firm $j$ in year $t$.

$\triangle R E C_{j, t}=$ change in net receivables $($ Compustat item 2$)$ for firm $j$ in year $t$.

$P P E_{j, t}=$ gross property, plant and equipment (Compustat item 7) for firm $j$ in year $t$.

$j \quad=\quad$ index for the client firm.

$t \quad=$ index for the firm-year.

The error term, $\varepsilon_{j, t}$, in Model (1) represents the discretionary component of accruals, and is our measure of discretionary accruals, $d a$. We use the absolute values of discretionary accruals, $|d a|$, to measure audit quality.

\section{Restatements as the proxy for audit quality}

The presence of a restatement is typically regarded as strong evidence that audit quality has been impaired (Kinney, Palmrose \& Scholz, 2004; Palmrose \& Scholz, 2004). When an auditor issues a clean audit opinion on a client firm's misstated financial statements, it is likely that the auditor's effort was insufficient and the audit was of low quality. While the 
restatement analysis provides additional evidence on audit quality, it is likely that some of the Chinese listings were the target of SEC investigation, leading to restatements, and we are also unable to create a fully matched sample of similar companies to reliably compare restatement rates across all combinations of auditor location and size. The analysis must be interpreted with respect to these limitations.

Following Francis, Michas and Yu (2013) we use all types of restatements recorded in Audit Analytics. ${ }^{15}$ We form a dichotomous variable, restate, coded 1 for a firm-year if a client subsequently restates its financial statements, and 0 otherwise. Audit Analytics indicates the beginning and ending of restatement period (Audit Analytics field 'RES_BEGIN_DATE' and 'RES_END_DATE', respectively) and we use this information to identify the firm-years for which restated financial statements were issued. The restatement rate is $8 \%$ of the sample. ${ }^{16}$

\section{Allegations of financial misconduct as a proxy for audit quality}

Another measure of audit quality is the likelihood of fraud (Carcello \& Nagy, 2004). We identify firms sued by investors for securities fraud or prosecuted by the SEC for financial fraud (Ang et al., 2016). Information on alleged fraud is obtained from Stanford University's Securities Class Action Clearinghouse and SEC's Accounting and Auditing Enforcement Releases (AAERs). The dependent variable fraud is coded 1 for firms that experienced an allegation of financial fraud in the year, and 0 otherwise. ${ }^{17}$ 


\section{Model}

To examine the effect of auditor location and auditor size on audit quality, we estimate the following model adapted from Choi et al. (2012) for firm $j$ in year $t:^{18}$

Audit quality measure $\left(|d a|_{j, t}\right.$, restate $_{j, t}$ or fraud $\left._{j, t}\right)=$

$$
\begin{aligned}
& \alpha_{0}+\alpha_{1} \text { aud_us } s_{j, t}+\alpha_{2} \text { aud_small }_{j, t}+\alpha_{3} \text { aud_us } \times \text { aud_small }{ }_{j, t}+\alpha_{4} \text { aud_h }_{j, t} \\
& +\alpha_{5} \text { aud_midtier } r_{j, t}+\alpha_{6} \text { nas }_{j, t}+\alpha_{7} \text { ind_spec }_{j, t}+\alpha_{8} \text { switch }_{j, t}+\alpha_{9} \text { tenure }_{j, t}+\alpha_{10} \text { lnage }_{j, t} \\
& +\alpha_{11} \text { lnta }_{j, t}+\alpha_{12} \text { roa }_{j, t}+\alpha_{13} \text { lev }_{j, t}+\alpha_{14} \text { loss }_{j, t}+\alpha_{15} \text { cfo }_{j, t}+\alpha_{16} \text { fin }_{j, t}+\alpha_{17} m t b_{j, t} \\
& +\alpha_{18} \text { nevada }_{j, t}+\alpha_{19} \text { soe }_{j, t}+\alpha_{20} \text { adr } r_{j, t}+\sum \alpha(\text { industry })+\sum \alpha(\text { year })+\xi_{, t}
\end{aligned}
$$

Definitions of the variables are described below, and provided in the Appendix.

\section{Variable of interest: small US audit firms}

To examine whether engaging a small US audit firm results in lower audit quality, we focus on the interaction effect between small auditor size and location in the US on audit quality. After controlling for auditor location (US, Hong Kong) and auditor size (Small, Mid-tier), the coefficient on the small US auditor variable (aud_us $\times$ aud_small) reflects the incremental audit quality for small auditors located in the US. We code an indicator variable (aud_us) 1 if the principal audit firm is located in the US and 0 otherwise. We initially define a small auditor (aud_small) as an audit firm that is neither Big 4 nor mid-tier and code it 1 , and 0 otherwise. As mid-tier firms are more similar to Big 4 in policy as to where the principal auditor is located, and typically consider themselves to be part of global networks, we define small audit firms as firms that are neither Big 4 nor mid-tier firms in the primary analysis. ${ }^{19}$ Panel A of Table 2 provides information on the size and location of the principal auditors. ${ }^{20}$ 
For this sample of US-listed Chinese firms, approximately $39 \%$ of firms engaged a 'small' principal auditor that is neither from a Big 4 nor mid-tier audit firm.

We also code an indicator variable (aud_hk) 1 if the audit firm is located Hong Kong and 0 otherwise. Evidence from Ke, Lennox and Xin (2015) suggests that the stronger institutional environment in Hong Kong should result in higher audit quality for firms audited by Hong Kong auditors. ${ }^{21}$ Approximately $41 \%$ of the sample audits have a principal auditor located in the US $(828 / 2,027), 32 \%$ of audits have a principal auditor located in China $(647 / 2,027)$ and $27 \%$ of audits are conducted by principal auditors located in Hong Kong $(553 / 2,027)^{22}$

Among audits for US-listed Chinese firms conducted by Big 4 auditors, most principal auditors are located in China (62\%, 583/941), followed by Hong Kong (37\%, 344/941). Very few audits conducted by a Big 4 firm have a principal auditor of record located in the US $(1 \%){ }^{23}$ These observations mostly appear early in the sample period and the results are not sensitive to exclusion of these observations from the analysis. The principal auditor for mid-tier audit firms in the sample are spread between mainland China, Hong Kong and the US. Consistent with the regulatory costs involved with registering with the PCAOB, the small auditors are primarily located in the US or Hong Kong. For the audits conducted by small auditors, the majority have a principal auditor located in the US (90\%, 709/786) with the other location of choice being Hong Kong. For ease of comparison, Panels $\mathrm{B}, \mathrm{C}$ and $\mathrm{D}$ of Table 2 report mean accruals, frequency of restatements, and number of fraud allegations, respectively, by size of auditor and principal auditor location. 


\section{Control variables}

\section{Audit characteristics}

An auditor industry specialist is expected to provide better quality audit. Auditor industry specialisation reduces the likelihood of restatements (Romanus, Maher \& Fleming, 2008). We use the portfolio share approach to calculate industry specialisation. We construct the portfolio share measure by calculating the ratio of the sum of total fees earned from all client firms of auditor $i$ in a two-digit SIC industry in year $t$ to the total sum of total fees earned from all client firms of auditor $i$ summed over all $K$ industries in year $t$ (Krishnan, 2003; Almutairi, Dunn \& Skantz, 2009). We form a dichotomous variable, ind_spec, coded 1 if the auditor is classified as a specialist in the industry and 0 otherwise. The auditor is classified as a specialist in industry $k$ if the portfolio share for industry $k$ is in the top $10 \%$ of the audit firm's portfolio share for all $K$ industries in year $t$ (Balsam, Krishnan \& Yang, 2003; Almutairi et al., 2009). The auditor is classified as a non-specialist in all other industries for that year (Almutairi et al., 2009).

High levels of non-audit service fees can create an economic bond that can reduce the auditor's objectivity and professional scepticism (Kinney et al., 2004; Francis \& Yu, 2009). We include proportion of non-audit fees (nas) measured by non-audit fees divided by total fees paid to the auditor. Clients of longer tenure auditors report lower discretionary accruals (Myers, Myers \& Omer, 2003) and a lower likelihood of fraudulent misconduct (Carcello \& Nagy, 2004). We include tenure, measured as the number of years of auditor tenure.

Economic and operating characteristics 
Audit quality can be impacted by age of the firm, size of the firm, growth prospects, profitability and financing. Firm age relates to internal control strength and can affect the likelihood of a restatement (Romanus et al., 2008) or the likelihood of committing financial misconduct (Carcello \& Nagy, 2004). We include lnage, measured as the natural logarithm of the number of years of listing. We include log of total assets $($ lnta $)$ because firm size affects the likelihood of a restatement (Palmrose \& Scholz, 2004) and fraud (Carcello \& Nagy, 2004). Firms with higher growth are associated with a higher likelihood of fraud (Carcello \& Nagy, 2004). To control for growth, we include market-to-book ratio (mtb) (Krishnan, 2003). Firms that are performing poorly and in financial difficulties are more likely to restate (Becker et al., 1998; Ahmed \& Goodwin, 2007) or engage in fraudulent misconduct (Chen et al., 2006; Ang et al., 2016). We include roa to capture firm profitability and lev and loss as measures of financial difficulties. Return on assets (roa) is calculated as income before extraordinary items deflated by lagged total assets. Leverage (lev) is calculated as total liabilities divided by total assets. We also include loss, an indicator variable coded 1 if a client firm reported negative net income. Poor operating cash flows (cfo) are associated with higher earnings management (Frankel, Johnson \& Nelson, 2002) which can increase the likelihood of restatements. We include operating cash flows measured as cash flow from operating activities deflated by total assets. We include the need for financing, measured by additional cash raised deflated by total assets (fin), as this is positively associated with the level of discretionary accruals (Dechow, Sloan \& Sweeney, 1996). 
Diversification, governance, type of listing and fixed effects

An indicator variable for incorporation in Nevada (nevada) is included to control for the firm's selection of a weaker corporate governance environment (Kobayashi \& Ribstein, 2011). US-listed Chinese companies that cross list as American Depositary Receipts (ADRs) have better audit quality than Chinese companies directly listed on US exchanges. An indicator variable is included for ADRs $(a d r)$. We include an indicator variable for stateowned enterprises, soe, because internal monitoring mechanisms are weaker in state-owned enterprises (Hou \& Moore, 2012) and this could potentially affect earnings management. We include year and industry fixed effects to reduce potential for bias from omitted variables and to reduce heteroscedasticity.

\section{Auditor-choice model}

We first examine the choice of auditor because auditor choices and audit quality measures are potentially endogenous. Selection bias can occur due to factors that are observable or factors that are non-observable to the researcher (Tucker, 2010). We use the two-stage inverse Mills ratio approach to address selection bias due to unobservable factors (Tucker, 2010). Similar to Kim, Chung and Firth (2003), we employ a two-stage approach where we first estimate the following probit auditor-choice model and compute the inverse Mills ratio:

$\operatorname{Pr}($ Small US auditor $)=$

$$
\begin{aligned}
& \alpha_{0}+\alpha_{1} \text { nas }_{j, t}+\alpha_{2} \text { ind_spec }_{j, t}+\alpha_{3} \text { switch }_{j, t}+\alpha_{4} \text { tenure }_{j, t}+\alpha_{5} \text { lnage }_{j, t}+\alpha_{6} \text { lnta }_{j, t}+ \\
& \alpha_{7} \text { roa }_{j, t}+\alpha_{8} \text { lev }_{j, t}+\alpha_{9} \text { loss }_{j, t}+\alpha_{10} \text { cfo }_{j, t}+\alpha_{11} \text { fin }_{j, t}+\alpha_{12} \text { mtb }_{j, t}+\alpha_{13} \text { nevada }_{j, t}+ \\
& \alpha_{14} \text { soe }_{j, t}+\alpha_{15} \text { adr }_{j, t}+\sum \alpha(\text { industry })+\sum \alpha(\text { year })+\xi_{, t}
\end{aligned}
$$


Definitions of the variables are as previously described and provided in the Appendix.

In the second stage, we include the Mills ratio in our model of audit quality.

\section{RESULTS}

\section{Descriptive statistics}

Table 3 reports the descriptive statistics partitioned by the location of the principal auditor: China, Hong Kong and the US. Firms that engage a mainland Chinese or a Hong Kong auditor on average are larger in size, have a greater proportion of non-audit fees, higher audit fees and total fees. We also find that firms that engage a $\mathrm{HK}$ auditor have more state ownership. Firms that engage a US auditor are more likely to have poorer operating performance, higher losses, lower cash flow from operations, greater financing needs, and are more likely to have incorporated in Nevada.

The comparisons of means suggests that the level of discretionary accruals $(|d a|)(t=$ -8.211 , untabulated) and the probability of restatement $(t=-7.502$, untabulated $)$ are higher for firms audited by a US principal auditor in comparison to an auditor in Hong Kong or mainland China. Firms with a US auditor also have a higher probability of experiencing an allegation of fraud ( $t=-2.652$, untabulated). This would seemingly suggest US audits were of lower quality, but this analysis must be carefully interpreted because the audits with a principal auditor in mainland China are more likely to have been conducted by a Big 4 auditor than the audits with a US or Hong Kong principal auditor.

\section{Choice of auditor}


Table 4 presents the results of a probit model that examines the probability of choosing a small US auditor. As would be expected, smaller companies are more likely to choose a small US auditor $(p<0.01)$. Chinese firms that register in Nevada $(p<0.01)$ and with stronger operating performance $(p<0.05)$ are more likely to choose a small US auditor. We also find that firms that list as an ADR are less likely to choose a small US auditor $(p<0.01)$.

\section{Results using discretionary accruals as the proxy for audit quality}

Panel A of Table 5 reports the multivariate analysis of discretionary accruals. The model fit for all models is reasonable with the adjusted $R^{2}$ ranging from $18 \%$ to $33 \%$. Despite the unusual sample, the coefficients on the control variables are mostly in line with prior studies. For Column 1, the coefficients on size (lnta) and operating cash flows ( $c f o$ ) are negative, indicating that larger firms with greater operating cash flows tend to have lower levels of discretionary accruals. The coefficients on roa, $m t b$ and fin are positive, suggesting that client firms with higher profitability, higher growth and with greater financing needs manage earnings more aggressively. We find a significant negative coefficient on the interaction term aud_us $\times$ aud_small $(p<0.05) .{ }^{24}$ This suggests that discretionary accruals are higher, consistent with lower audit quality, when the principal auditor is a small US audit firm. We also find a significantly negative coefficient on aud_small $(p<0.05)$, suggesting that firms audited by small auditors that are not located in the US have lower discretionary accruals. As the sample does not contain any small PCAOB registered audit firms located in mainland China, this result is consistent with small auditors located in Hong Kong having a higher audit quality. ${ }^{25}$ We obtain similar results when using income increasing discretionary accruals 
(Column 2) as the measure of discretionary accruals. ${ }^{26}$

We also constructed a propensity matched sample by obtaining propensity scores estimated from regressing the probability of a small auditor-client mismatch against all other control variables in our model. We then conducted a one-to-one nearest neighbour match using a caliper of 0.2. The results are reported in Column 3 and are mostly consistent with the other model specifications. The coefficient on the interaction term between the small auditor and US auditor indicator variables is marginally significant, indicating higher discretionary accruals and a poorer audit quality. We obtain similar results when using the inverse Mills ratio approach to mitigate potential selection bias (Column 4).

Panel B of Table 5 reports results for specific sub-sample comparisons. We first consider differences in audit quality within the small auditor market segment. Column 1 reports results for the sub-sample audited by small auditors. The comparison in this segment is between audit quality as proxied by discretionary accruals, between small auditors in the US and small auditors in Hong Kong. For the small auditor market segment, the discretionary accruals are higher for the principal auditors located in the US in comparison to auditors located in Hong Kong (aud_us). Column 2 reports results for a sub-sample of mid-tier auditors. This segment of the market includes auditors located in mainland China, Hong Kong and the US. For the mid-tier market segment we do not find any significant differences in audit quality by auditor location. We also find no significant difference in quality by location for large auditors within this small sample (not tabulated).

As can be seen from Panel A of Table 2, the primary choice of auditor for this sample of Chinese companies is between the smaller US auditors (709, 35\% of sample) and the Big 4 
auditors with the principal audit office in China $(583,29 \%)$. While this small to large auditor comparison is unusual and must be interpreted with respect to potential differences in both auditor and client characteristics, the comparison reflects the most common choice of auditor. Column 3 in Panel B of Table 5 reports results comparing these sub-samples. In terms of discretionary accruals, the small US auditors have higher discretionary accruals consistent with a lower audit quality than the Big 4 auditors managing the audit from China.

In summary, when using discretionary accruals as a proxy for audit quality, we find that when the client firm is audited by a small US auditor, discretionary accruals are higher and accordingly audit quality is poorer relative to an audit by a small Hong Kong auditor or a principal auditor located in mainland China (the base case in the regression models in Table 5). While this result is consistent with PCAOB concerns regarding lower audit quality for small US auditors supervising international audits, the analysis highlights the need to compare alternative available choices of PCAOB-registered auditors.

\section{Results using the likelihood of restatements as a proxy for audit quality}

The results for the restatement analysis are presented in Table 6. The models are estimated with indicator variables for the size and location of the principal auditor, and then with an interaction term for small US auditors. The pseudo $R^{2}$ for the models is $17 \%$. For Column 1 the coefficients on nas, switch and tenure are significantly positive. The results suggest that firms are more likely to restate their earnings when they have higher levels of non-audit services, switched auditor and have auditors with longer tenure. The coefficients on lev and $a d r$ are significantly negative, indicating that firms are less likely to restate their earnings 
when they have higher leverage and when they listed as an ADR. We find a positive coefficient on the interaction term that is marginally significant ( $p<0.10$, two-tailed). The results indicate that we could not reject the hypothesis that Chinese companies with small US auditors are more likely to have restatements than companies with other auditors. To address possible endogenity concerns, we also employ a propensity matched sample (Column 2) and a sample using the inverse Mills ratio approach (Column 3) and obtain similar results.

\section{Results using the likelihood of experiencing allegations of financial misconduct for audit quality}

The logistic regression results using the likelihood of experiencing an allegation of financial misconduct as a proxy for audit quality are reported in Table 7 . The goodness of fit is reasonable with the pseudo $R^{2}$ ranging from 20 to $30 \%$. The coefficients on the control variables lnta, lnage, nas, tenure, lev and nevada are significant, indicating that firms are more likely to experience a financial allegation when they are larger, older, have higher leverage, higher levels of non-audit services, shorter auditor tenure and are incorporated in Nevada. We also find that state-owned enterprise (soe) have a lower likelihood of experiencing a fraud allegation, consistent with Chen et al. (2006) who found that fraud firms have lower state ownership.

We do not find consistent evidence that the clients of the small US auditors (aud_us $\times$ aud_small) experience more allegations of fraud. We find that clients of small auditors (aud_small) have a higher probability of experiencing an allegation of financial misconduct $(p<0.05)$. Contrary to typical expectations, we find that firms audited by US auditors 
(aud_us) have a higher probability of experiencing an allegation of financial misconduct $(p<$ 0.05), which may relate to the ability to recover funds from litigation rather than audit quality. We obtain similar results when using the inverse Mills ratio approach (Column 3). In the propensity matched sample (Column 2), the coefficient on US auditors is significant $(p<$ $0.05)$ but the coefficient on small auditor is not significant $(p>0.10)$.

Overall, Chinese companies listed in the US with smaller US auditors have higher levels of discretionary accruals and marginally higher restatements, but not significantly higher allegations of fraud.

\section{Further analysis}

The results reported apply to small auditors but not to 'all non-Big 4 auditors'. If mid-tier auditors are combined with small auditors as 'all non-Big 4 auditors' then we find no significance for US non-Big 4 auditors for discretionary accruals or restatements. We find lower allegations of fraud for US non-Big 4 relative to the full sample using this approach. This evidence is consistent with lower audit quality being confined to the small audit segment.

For the analysis of discretionary accruals and restatements, the results for the coefficients on the small US auditor variable are robust to the exclusion of mid-tier firms from the sample. For the probability of an allegation of fraud, however, we find higher allegations for clients of small auditors but we do not find higher allegations for small US auditors. 


\section{CONCLUSION}

PCAOB Staff Audit Practice Alert No. 6 (PCAOB, 2010) draws attention to the potential issue of audit firms supervising audits of foreign operations for which they are unable to adequately fulfil the role of principal auditor. This study provides some evidence supporting the SEC's and the PCAOB's claims of the inabilities of some US auditors to conduct appropriate quality audits for US-listed Chinese firms (PCAOB, 2011; SEC, 2011). We specifically find that US-listed Chinese companies audited by small US auditors have higher levels of discretionary accruals and are marginally more likely to have restatements.

Because the US has the most stringent legal and regulatory environment, US auditors would be expected to provide the highest audit quality. Our empirical results do not, however, support this perspective when looking at audits of Chinese firms supervised by small US audit firms. A possible explanation is that smaller US auditors did not have adequate quality control processes in place to supervise audits conducted at a distance (PCAOB, 2010).

The results must, however, be interpreted with respect to significant methodological limitations. First, it is very difficult to disentangle the effects of auditor-selection bias in this context. While we provide results using propensity score matched samples, we cannot fully eliminate the explanation that the small audit firms have smaller and riskier clients with lower financial reporting quality. Second, the direction of causality is unclear in that a client firm with lower financial reporting quality might tend to choose a smaller auditor located away from the client's home country. The causality in that case would suggest that the high level of 
discretionary accruals leads to an auditor-client location mismatch. Third, consistent with similar studies examining audit quality, the proxies used for audit quality are subject to numerous limitations and the results must be interpreted with respect to these limitations. Finally, this study does not address the on-going issue of the inspection of audit firms. Future research is needed to better examine the impact on audit quality of the local and PCAOB inspection regimes, and also the impact of PCAOB attention to specific issues, such as the issue of auditors' ability to supervise international audits, within the inspection regime.

\section{ACKNOWLEDGEMENTS}

We would like to acknowledge comments from Elizabeth Carson, Tej Kala, Robyn Moroney, Gary Monroe and participants at the AFAANZ conference 2015, the doctoral seminar at the University of California Berkeley, and the workshops at the Australian National University and Monash University. All errors are our responsibility.

\section{NOTES}

1. For example, an SEC investigation found that Sherb \& Co. LLP, a US audit firm with six partners (per PCAOB inspection report dated 2007), 'falsely represented in audit reports that they had conducted the audits in accordance with US auditing standards when it fact they were riddled with failures and improper professional conduct' (SEC, 2013).

2. In the 27-month period ending 31 March 2010, at least 40 US accounting firms with fewer than five partners and fewer than two professional staff issued audit reports on financial statements of firms whose operations were substantially in mainland China and Hong Kong (PCAOB, 2010).

3. An accounting firm cannot serve as a principal auditor and report as such on the financial statements unless the firm's participation in the audit is 'sufficient'. AS 573, paragraph 4: 'The auditor considering whether he may serve as principal auditor may have performed all but a relatively minor portion of the work, or significant parts of the audit may have been performed 
by other auditors. In the latter case, he must decide whether his own participation is sufficient to enable him to serve as the principal auditor and to report as such on the financial statements. In deciding this question, the auditor should consider, among other things, the materiality of the portion of the financial statements he has audited in comparison with the portion audited by other auditors, the extent of his knowledge of the overall financial statements, and the importance of the components he audited in relation to the enterprise as a whole' [emphasis added].

4. There is a different unresolved issue with the inspection process to ensure audit quality during the period of this study. PCAOB audit inspection of US-listed China-based firms is restricted in mainland China and Hong Kong (PCAOB, 2014). The China Securities Regulatory Commission (CSRC) has asserted that allowing the PCAOB to enter China to conduct audit inspections violates China's national sovereignty and that the PCAOB should rely on the work of the CSRC (China Securities Regulatory Commission, 2009). Despite the PCAOB signing a memorandum of understanding with the Chinese regulators in relation to audit inspections, there was little cooperation during the period of this study (Memorandum of understanding on enforcement between the Public Company Accounting Oversight Board of the United States and the China Securities Regulatory Commission and the Ministry of Finance in China, 13 May 2013). Carcello et al. (2014) demonstrate the economic significance to investors of this issue by documenting a negative reaction to news that US regulators would be unable to provide oversight of Chinese auditors. To the extent that China-based auditors, including the Big 4 and BDO, had lower audit quality arising from limitations on inspections during this period, then this would work against our tests of the lower audit quality of small US auditors relative to larger auditors with offices in China most impacted by this issue.

5. Chinese firms listed on the major US stock exchanges fall into three broad categories: large stateowned companies ranked among the world's largest, such as Sinopec Group and China National Petroleum; private firms that have completed an initial public offering in the US market; and smaller private firms that listed on the US markets through reverse mergers.

6. The typical allegation was that firms' financial reports were significantly different from their real operating situations. For example, AgFeed Industries Inc., a Chinese animal feed company, listed in the US in 2006. It is alleged to have conducted a massive accounting fraud in which they repeatedly reported fake revenues from their China operations in order to meet financial targets and prop up the stock price. Executives allegedly lied to outside auditors (SEC, 2014). 
7. In the context of Chinese companies, Ke et al. (2015) examined the audit quality of firms audited by Big 4 auditors and found that the weak institutional environment in China is associated with Big 4 firms providing lower-quality audits to companies that are only listed in mainland China as compared to those that are also cross-listed in Hong Kong.

8. In reviewing the literature Hanes (2013) lists factors associated with distance that would reduce the quality of audit including: less face-to-face communication and differences in norms and cultures which affect the efficiency and effectiveness of coordination; problems with knowledge sharing in which knowledge often cannot be shared perfectly across offices; the reduction in the effectiveness of work monitoring and work flows between team members. Lyubimov, Arnold and Sutton (2013) further show that outsourcing and offshoring of audit services reduce audit quality in an experimental setting.

9. An example would be where the US audit firm's personnel did not travel to China during the audit, substantially all the documentation was maintained by the local audit firm in China, and the principal auditor in the US did not consider sufficient evidential matter to form a reasonable basis for an audit opinion (PCAOB, 2010).

10. We include all Chinese listings with available data rather than restricting the analysis to reverse mergers. Lee et al. (2015) conclude that they find no evidence that reverse mergers are more problematic than other firms in terms of operating performance or stock returns.

11. Shandong Haoxin, an audit firm based in mainland China audited the 2011 financial statement of Ambow Education Holdings. The firm has seven partners and is registered with the PCAOB as of 2012. Our results are robust to inclusion of this observation.

12. To check that these selection criteria were effective in identifying firms based in China, we randomly selected 50 firms to verify their Chinese background. We accessed the company's website and read the description of main business and company history to ascertain that the major business operation is in mainland China and that the firm originated as a Chinese company.

13. Other proxies for audit quality were considered. Based upon CRSP delisting code there are relatively few company failures (bankruptcy or liquidation) in the sample to facilitate an analysis of the accuracy of going concern modifications, but there is no evidence of a high incidence of type 2 errors (failure given no going concern qualification). There is also no evidence of a systematic movement towards better quality auditors when switching auditors. 
14. We did not find significant differences in audit quality using a performance-matched discretionary accruals model. A likely explanation is that performance matching reduces the power of the test (Keung \& Shih, 2014). Keung and Shih (2014, p. 741) highlight that 'many studies that use only ROA-matched estimates of discretionary accruals in their analyses generate insignificant test results' and they caution against the use of performance matching.

15. For a discussion of reasons for restatements, see Plumlee and Yohn (2010). Some studies examine only 'adverse' restatements (Blankley, Hurtt \& MacGregor, 2012). Francis et al. (2013) argue that this screens out some income-increasing restatements and use all restatements. Given that we study restatements within a small sample, we use all restatements as the more powerful test. The restatements include missed disclosures, inadequate disclosure controls and misapplication of accounting principles (e.g. SFAS 133, expensing reverse merger costs and revenue recognition criteria).

16. This rate of restatement is comparable to studies using samples of all US-listed firms (e.g., restatement rate is $11 \%$ in Francis et al., 2013).

17. The year of allegation is determined from the class action period start date or period of misstated reports as identified in AAERs.

18. Zmijewski's (1984) financial distress score, zmij, is excluded from the model due to multicollinearity between ZMIJ and leverage (lev) (Pearson correlation $=0.80)$.

19. The results reported are not sensitive to including some smaller mid-tier audit firms that do not have a global audit network as small firms.

20. We use the US tiers rather than say the Chinese top-10 classification as this fits the data better, likely due to this sample effectively being restricted to auditors registered with the PCAOB. For more background on the Chinese audit market, see Mo, Rui and Wu (2015).

21. Audit quality is not, however, unambiguously higher for auditors located in Hong Kong. PKF (Hong Kong)'s registration from the PCAOB was revoked for a period of three years from January 2016 following a failure to adequately respond to an investigation regarding the audit of a China-based issuer (PCAOB, 2016).

22. The sample excludes the small number of auditors not located in mainland China, Hong Kong or the US.

23. SEC filings were reviewed for these observations to ensure that a US office was listed as the principal auditor. 
24. The sum of the coefficients for aud_us and aud_us $\times$ aud_small is not significantly different from zero (Prob $>F=0.984)$.

25. When we exclude the aud_us $\times$ aud_small variable and include an interaction term 'aud_hk $\times$ aud_small', we find a negative coefficient on the interaction term, suggesting that small auditors located in Hong Kong have lower client accruals and higher audit quality. We cannot, however, include both interactions terms ('aud_us $\times$ aud_small' and 'aud_hk $\times a u d \_s m a l l$ ') in our primary model due to the absence of small auditors located in mainland China.

26. We re-estimated our model with income-decreasing accruals $(n=559)$ using the full sample, propensity matched sample and sample with inverse Mills ratio. We do not find significance on the coefficients for any measures of auditor size and auditor country.

\section{REFERENCES}

Ahmed, K. \& J. Goodwin, J. (2007), 'An empirical investigation of earnings restatements by Australian firms', Accounting \& Finance, Vol. 47, No. 1, pp. 1-22.

Almutairi, A. R., Dunn, K. A. \& Skantz, T. (2009), 'Auditor tenure, auditor specialization, and information asymmetry', Managerial Auditing Journal, Vol. 24, No. 7, pp. 600-23.

Ang, J. S., Z. Jiang \& C. Wu. (2016), 'Good apples, bad apples: Sorting among Chinese companies traded in the US', Journal of Business Ethics, Vol. 134, No. 4, pp. 611-29.

Balsam, S., Krishnan, J. \& Yang, J. S. (2003), 'Auditor industry specialization and earnings quality', Auditing: A Journal of Practice \& Theory, Vol. 22, No. 2, pp. 71-97.

Bartov, E., Gul, F. A. \& Tsui, J. S. (2000), 'Discretionary-accruals models and audit qualifications', Journal of Accounting and Economics, Vol. 30, No. 3, pp. 421-52.

Becker, C. L., DeFond, M. L., Jiambalvo, J. \& Subramanyam, K. (1998), 'The effect of audit quality on earnings management', Contemporary Accounting Research, Vol. 15, No. 1, pp. 1-24.

Blankley, A. I., Hurtt, D. N. \& MacGregor, J. E. (2012), 'Abnormal audit fees and restatements', Auditing: A Journal of Practice \& Theory, Vol. 31, No. 1, pp. 79-96.

Carcello, J. V., Carver, B. T., Lennox, C. S. \& Neal, T. L. (2014), 'When bonding fails: Audit firm oversight of US-listed Chinese companies', Working paper, University of Tennessee.

Carcello, J. V. \& Nagy, A. L. (2004), 'Audit firm tenure and fraudulent financial reporting', Auditing: A Journal of Practice \& Theory, Vol. 23, No. 2, pp. 55-69.

Carson, E. (2009), 'Industry specialization by global audit firm networks', The Accounting Review, Vol. 84, No. 2, pp. 355-82. 
Chen, G., Firth, M., Gao, D. N. \& Rui, O. M. (2006), 'Ownership structure, corporate governance, and fraud: Evidence from China', Journal of Corporate Finance, Vol. 12, No. 3, pp. 424-48.

China Securities Regulatory Commission (2009), 'Public company accounting oversight board; notice of filing of proposed amendment to board rules relating to inspection', Beijing: CSRC.

Choi, J.-H., Kim, J.-B., Liu, X. \& Simunic, D. A. (2008), 'Audit pricing, legal liability regimes, and Big 4 premiums: Theory and cross-country evidence', Contemporary Accounting Research, Vol. 25, No. 1, pp. 55-99.

Choi, J.-H., Kim, J.-B., Qiu, A. A. \& Zang, Y. (2012), 'Geographic proximity between auditor and " client: How does it impact audit quality?' Auditing: A Journal of Practice \& Theory, Vol. 31, No. 2, pp. 43-72.

Dechow, P. M., Sloan, R. G. \& Sweeney, A. P. (1996), 'Causes and consequences of earnings manipulation: An analysis of firms subject to enforcement actions by the SEC', Contemporary Accounting Research, Vol. 13, No. 1, pp. 1-36.

DeFond, M. L. \& Subramanyam, K. (1998), 'Auditor changes and discretionary accruals', Journal of Accounting and Economics, Vol. 25, No. 1, pp. 35-67.

Francis, J. R., Michas, P. N. \& Yu, M. D. (2013), 'Office size of Big 4 auditors and client restatements', Contemporary Accounting Research, Vol. 30, No. 4, pp. 1626-61.

Francis, J. R. \& Yu, M. D. (2009), 'Big 4 office space and audit quality', The Accounting Review, Vol. 84, No. 5, pp. 1521-52.

Frankel, R. M., Johnson, M. F. \& Nelson, K. K. (2002), 'The relation between auditors' fees for nonaudit services and earnings management', The Accounting Review, Vol. 77, pp. 71-105.

Gillis, P. L. (2011), 'The Big Four in China: Hegemony and counter-hegemony in the development of the accounting profession in China', Macquarie University, Sydney.

Hanes, D. R. (2013), 'Geographically distributed audit work: Theoretical considerations and future directions', Journal of Accounting Literature, Vol. 32, No. 1, pp. 1-29.

Hou, W. \& Moore, G. (2012), 'Player and referee roles held jointly: The effect of state ownership on China's regulatory enforcement against fraud', Journal of Business Ethics, Vol. 95, Supplement 2, pp. 317-35.

Hung, M., Ma, Z. \& Wang, R. (2014), 'Big Four global networks and audit quality differentiation: Evidence from US-listed foreign firms', University of Queensland.

Ke, B., Lennox, C. \& Xin, Q. (2015), 'The effect of China's weak institutional environment on the quality of Big Four audits', The Accounting Review, Vol. 90, No. 4, pp. 1591-619. 
Keung, E. \& Shih, M. S. (2014), 'Measuring discretionary accruals: Are ROA-matched models better than the original Jones-type models?' Review of Accounting Studies, Vol. 19, No. 2, pp. 73668.

Kim, J. B., Chung, R. \& Firth, M. (2003), 'Auditor conservatism, asymmetric monitoring, and earnings management', Contemporary Accounting Research, Vol. 20, No. 2, pp. 323-59.

Kinney, W. R., Palmrose, Z.-V. \& Scholz, S. (2004), ‘Auditor independence, non-audit services, and restatements: Was the US government right?' Journal of Accounting Research, Vol. 42, No. 3, pp. 561-88.

Kobayashi, B. H. \& Ribstein, L. E. (2011), 'Nevada and the market for corporate law', Seattle University Law Review, Vol. 35, pp. 1165-88.

Krishnan, G. V. (2003), 'Does Big 6 auditor industry expertise constrain earnings management?' Accounting Horizons, Vol. 17, Supplement, pp. 1-16.

Lee, C. M., Li, K. K. \& Zhang, R. (2015), 'Shell games: The long term performance of Chinese reverse merger firms', The Accounting Review, Vol. 90, No. 4, pp. 1547-89.

Lyubimov, A., Arnold, V. \& Sutton, S. G. (2013), 'An examination of the legal liability associated with outsourcing and offshoring audit procedures', Auditing: A Journal of Practice \& Theory, Vol. 32, No. 2, pp. 97-118.

Mo, P. L., Rui, O. M. \& Wu, X. (2015), 'Auditors' going concern reporting in the pre- and postbankruptcy law eras: Chinese affiliates of Big 4 versus local auditors', The International Journal of Accounting, Vol. 50, No. 1, pp. 1-30.

Myers, J. N., Myers, L. A. \& Omer, T. C. (2003), 'Exploring the term of the auditor-client relationship and the quality of earnings: A case for mandatory auditor rotation?' The Accounting Review, Vol. 78, No. 3, pp. 779-99.

Palmrose, Z. V. \& Scholz, S. (2004), 'The circumstances and legal consequences of non-GAAP reporting: Evidence from restatements', Contemporary Accounting Research, Vol. 21, No. 1, pp. 139-80.

PCAOB (2010), 'Auditor considerations regarding using the work of other auditors and engaging assistants from outside the firm: Staff Audit Practice Alert No. 6', Washington, DC: PCAOB.

PCAOB (2011), 'Activity summary and audit implications for reverse mergers involving companies from the China region: January 1, 2007 through March 31, 2010', Research Note \#2011-P1, Washington, DC: PCAOB. 
PCAOB (2014), 'Issuers that are audit clients of PCAOB-registered firms from non-US jurisdictions where the PCAOB is denied access to conduct inspections', Washington, DC: PCAOB.

PCAOB (2016), 'PCAOB release no. 105-2016-00, in the matter of PKF [Hong Kong]', Washington, DC: PCAOB.

Plumlee, M. \& Yohn, T. L. (2010), 'An analysis of the underlying causes attributed to restatements', Accounting Horizons, Vol. 24, No. 1, pp. 41-64.

Romanus, R. N., Maher, J. J. \& Fleming, D. M. (2008), 'Auditor industry specialization, auditor changes, and accounting restatements', Accounting Horizons, Vol. 22, No. 4, pp. 389-413.

Securities and Exchange Commission (SEC) (2011), 'Reverse mergers: SEC Investor Bulletin', available at: http://www.sec.gov/investor/alerts/reversemergers.pdf.

Securities and Exchange Commission (SEC) (2012), 'SEC charges China affiliates of Big 4 accounting firms with violating US securities laws in refusing the produce documents', Press release, Washington, DC: SEC.

Securities and Exchange Commission (SEC) (2013), 'SEC charges New York-based audit firm and four accountants for failures in audits of China-based companies', available at: https://www.sec.gov/news/pressrelease/detail/pressrelease/1370540289271.

Securities and Exchange Commission (SEC) (2014), 'SEC charges animal feed company and top executives in China and US with accounting fraud', available at: https://www.sec.gov/news/pressrelease/detail/pressrelease/1370541102314.

Tucker, J. W. (2010), 'Selection bias and econometric remedies in accounting and finance research', Journal of Accounting Literature, Vol. 29, pp. 31-57.

Zmijewski, M. E. (1984), 'Methodological issues related to the estimation of financial distress prediction models', Journal of Accounting Research, Vol. 22, Supplement, pp. 59-82.

\section{AUTHOR PROFILES}

Chien Minh Dang is an accountant with Tailored Accounts in Canberra, Australia. This research was conducted while Chien Minh Dang was an honours student at the College of Business and Economics at the Australian National University.

Neil Fargher is a professor in the College of Business and Economics at the Australian National University. His major fields of research include auditing and financial accounting. 
Gladys Lee is a senior lecturer in the Faculty of Business and Economics at the University of Melbourne. Her research interests include audit quality, the use of whistleblowing to uncover financial misconduct, and the detection of fraud.

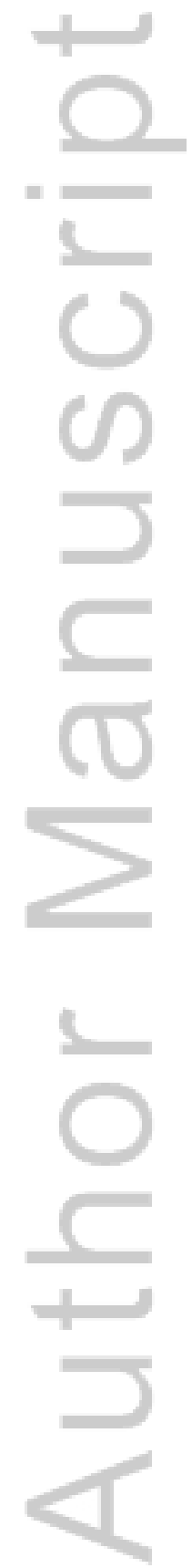

This article is protected by copyright. All rights reserved. 







\begin{tabular}{|c|c|}
\hline \multicolumn{2}{|c|}{ Firm's operating and economic characteristics } \\
\hline lnta & $=$ size, measured by the natural log of total assets (Compustat item 6) \\
\hline lnage & $=$ natural log of the number of years the client firm has been listed \\
\hline loss & $\begin{array}{l}=\text { indicator variable that captures whether the client firm reports a loss, } \\
\text { coded } 1 \text { if a firm's reported net income (Compustat item 172) is less than } \\
\text { zero }\end{array}$ \\
\hline roa & $\begin{array}{l}=\text { return on assets, calculated as income before extraordinary items deflated } \\
\text { by lagged total assets }\end{array}$ \\
\hline & $\begin{aligned}= & \text { leverage calculated as total liabilities (Compustat item 181) divided by } \\
& \text { total assets (Compustat item 6) }\end{aligned}$ \\
\hline$c f o$ & $=$ cash flow from operating activities (Compustat item 308) deflated by \\
\hline & total assets (Compustat item 6) \\
\hline & $\begin{aligned} &= \text { financing raised of client firm } j \text { in year } t \text {, measured as the sum of } \\
& \text { additional cash raised from issuance of long-term debt (Compustat item } \\
& \text { 111), common stock and preferred stock (Compustat item 108), deflated } \\
& \text { by total assets (Compustat item 6) }\end{aligned}$ \\
\hline$m t b$ & $\begin{aligned}= & \text { market-to-book ratio, calculated by taking (end of year share price } \times \\
& \text { common share outstanding) divided by ordinary equity }\end{aligned}$ \\
\hline nevad & $\begin{aligned}= & \text { indicator variable coded } 1 \text { if a client firm is incorporated in Nevada, and } \\
& 0 \text { otherwise (Audit Analytics field 'INC_STATE_NAME') }\end{aligned}$ \\
\hline$a d r$ & $=$ indicator variable coded 1 if the firm issues shares as an American \\
\hline soe & $\begin{array}{l}=\text { indicator variable coded } 1 \text { if the firm is a Chinese state-owned enterprise, } \\
\text { and } 0 \text { otherwise }\end{array}$ \\
\hline
\end{tabular}


No. of firm-year

observations

Observations for Chinese companies cross-listed in the US for which Audit

Analytics data is available

3,960

Less: missing audit fee data

Less: auditor not located in US, mainland China or Hong Kong

Less: missing financial data from Compustat

Less: outlier observation

Observations available for regressions

This table describes the sample selection process. The sample consists of 2,027 firm-year observations for 355 firms (auditees) registered with the SEC with corporate office in mainland China over the years 2000 to 2014 .

This article is protected by copyright. All rights reserved. 
Table 2: Sample characteristics

Panel A: Frequency of audits by auditor size and location

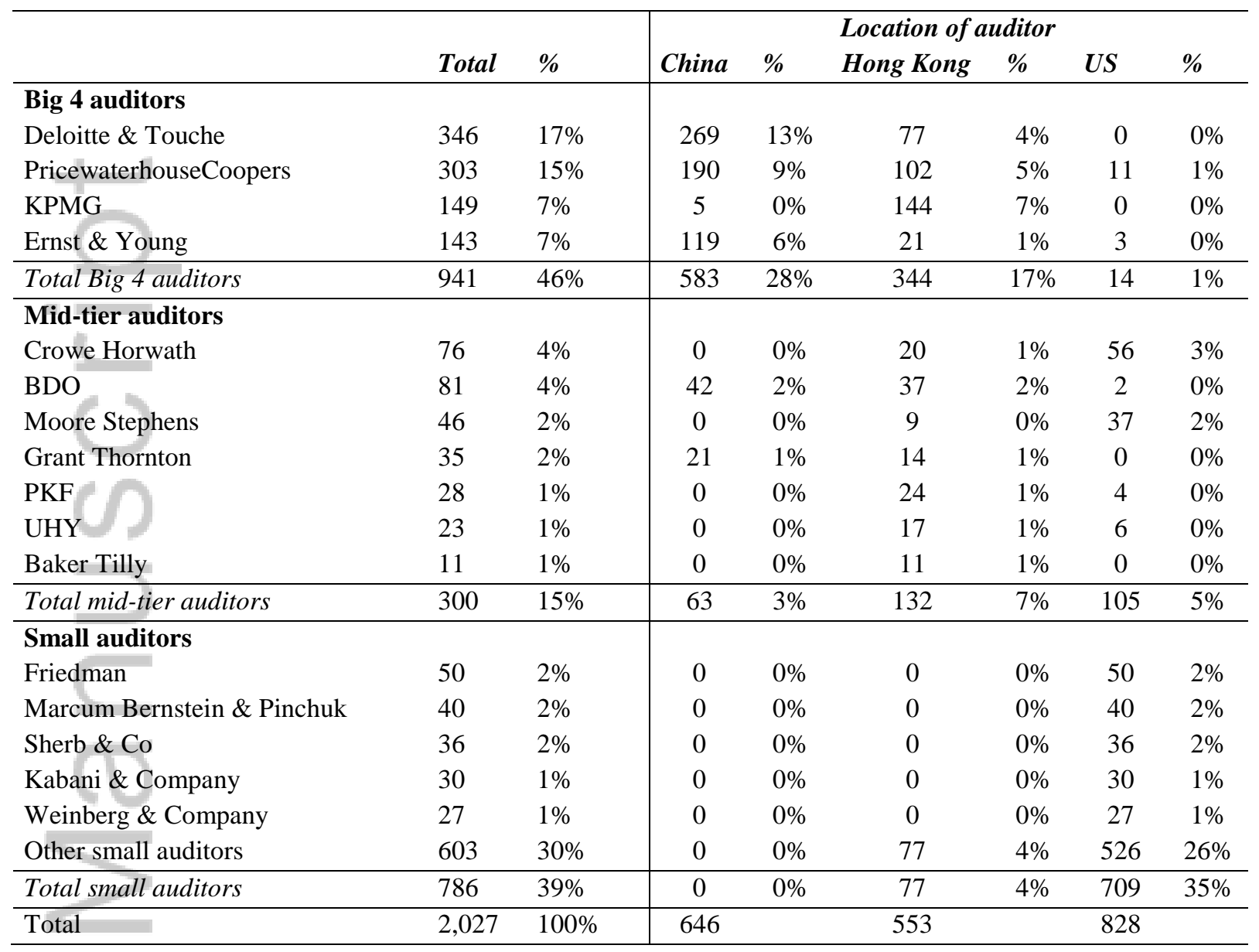

Panel B: Distribution of discretionary accruals by location and size of auditor

\begin{tabular}{|c|c|c|c|c|c|c|}
\hline \multirow{3}{*}{$\begin{array}{ll}\text { Auditor } & \text { Discretionary } \\
\text { size } & \text { accrual measure }\end{array}$} & \multicolumn{6}{|c|}{ Auditor location } \\
\hline & \multicolumn{2}{|l|}{ China } & \multicolumn{2}{|c|}{ Hong Kong } & \multicolumn{2}{|l|}{$U S$} \\
\hline & Mean & Median & Mean & Median & Mean & Median \\
\hline Big4 & 0.040 & 0.053 & 0.065 & 0.038 & 0.058 & 0.124 \\
\hline$|d a|$ & 0.150 & 0.089 & 0.152 & 0.083 & 0.220 & 0.135 \\
\hline \multirow{2}{*}{$\begin{array}{ll}\text { Mid-tier } & d a \\
& |d a|\end{array}$} & 0.089 & 0.082 & 0.092 & 0.094 & 0.200 & 0.191 \\
\hline & 0.182 & 0.110 & 0.171 & 0.137 & 0.242 & 0.162 \\
\hline \multirow[t]{2}{*}{ Small } & N/A & N/A & 0.102 & 0.098 & 0.247 & 0.120 \\
\hline & N/A & N/A & 0.197 & 0.138 & 0.309 & 0.127 \\
\hline
\end{tabular}


Panel C: Distribution of restatements by location and size of auditor

\begin{tabular}{|c|c|c|c|c|c|}
\hline & \multicolumn{5}{|c|}{ Number of firm-year observations } \\
\hline Location of auditor & RESTATE $=0$ & $\%$ & RESTATE $=1$ & $\%$ & Total \\
\hline Mainland China & 622 & $31 \%$ & 24 & $1 \%$ & 646 \\
\hline Hong Kong & 527 & $26 \%$ & 26 & $1 \%$ & 553 \\
\hline US & 719 & $35 \%$ & 109 & $5 \%$ & 828 \\
\hline Total & 1,868 & & 159 & & 2,027 \\
\hline \multicolumn{6}{|l|}{ Size of auditor } \\
\hline Big 4 & 913 & $45 \%$ & 28 & $1 \%$ & 941 \\
\hline Mid-tier & 271 & $13 \%$ & 29 & $1 \%$ & 300 \\
\hline Small & 684 & $34 \%$ & 102 & $5 \%$ & 786 \\
\hline Total & 1,868 & & 159 & & 2,027 \\
\hline
\end{tabular}

Panel D: Distribution of fraud allegations by location and size of auditor

\begin{tabular}{|c|c|c|c|c|c|}
\hline \multirow[b]{2}{*}{ Location of auditor } & \multicolumn{5}{|c|}{ Number of firm-year observations } \\
\hline & $F R A U D=0$ & $\%$ & $F R A U D=1$ & $\%$ & Total \\
\hline Mainland China & 598 & $30 \%$ & 48 & $2 \%$ & 646 \\
\hline Hong Kong & 509 & $25 \%$ & 44 & $2 \%$ & 553 \\
\hline US & 736 & $36 \%$ & 92 & $5 \%$ & 828 \\
\hline Total & 1,843 & & 185 & & 2,027 \\
\hline \multicolumn{6}{|l|}{ Size of auditor } \\
\hline Big 4 & 871 & $43 \%$ & 70 & $3 \%$ & 941 \\
\hline Mid-tier & 266 & $13 \%$ & 34 & $2 \%$ & 300 \\
\hline Small & 706 & $35 \%$ & 80 & $4 \%$ & 786 \\
\hline Total & 1,843 & & 184 & & 2,027 \\
\hline
\end{tabular}

This table provides descriptive information by the location of principal auditors in the sample. The sample consists of 2,027 firm-year observations for 355 China-based firms listed on the US stock exchanges over the years 2000 to 2014. Panel A provides the frequency of observations by size of auditor and location. Panels B, C and D provide data on the audit quality proxies by the principal auditor's location and size. Auditor location is coded based on the principal auditor's engagement office (Audit Analytics field 'AUDITOR_COUNTRY' \& 'AUDITOR_CITY'). 
Table 3: Descriptive statistics

\begin{tabular}{|c|c|c|c|c|c|c|c|c|c|c|c|c|}
\hline & \multicolumn{3}{|c|}{ Full sample } & \multicolumn{3}{|c|}{ Auditor located in China (aud_china) } & \multicolumn{3}{|c|}{ Auditor located in HK (aud_hk) } & \multicolumn{3}{|c|}{ Auditor located in US (aud_us) } \\
\hline & Mean & Median & Std dev. & Mean & Median & Std dev. & Mean & Median & Std dev. & Mean & Median & Std dev. \\
\hline \multicolumn{13}{|c|}{ Auditor location and size } \\
\hline aud_us & 0.408 & 0 & 0.492 & 0 & 0 & 0 & 0 & 0 & 0 & 1 & 1 & 0 \\
\hline aud_hk & 0.273 & 0 & 0.446 & 0 & 0 & 0 & 1 & 1 & 0 & 0 & 0 & 0 \\
\hline aud_china & 0.319 & 0 & 0.466 & 1.000 & 1 & 0 & 0 & 0 & 0 & 0 & 0 & 0 \\
\hline aud_big4 & 0.464 & 0 & 0.499 & 0.902 & 1.000 & 0.297 & 0.622 & 1.000 & 0.485 & 0.017 & 0.017 & 0.000 \\
\hline aud_midtier & 0.148 & 0 & 0.355 & 0.098 & 0.000 & 0.297 & 0.239 & 0.000 & 0.427 & 0.127 & 0.127 & 0.000 \\
\hline aud_small & 0.388 & 0 & 0.487 & N/A & N/A & N/A & 0.139 & 0.000 & 0.347 & 0.856 & 0.856 & 1.000 \\
\hline \multicolumn{13}{|c|}{ Audit quality measures } \\
\hline$|d a|$ & 0.215 & 0.103 & 0.389 & 0.153 & 0.091 & 0.249 & 0.163 & 0.098 & 0.237 & 0.299 & 0.131 & 0.522 \\
\hline restate & 0.078 & 0 & 0.269 & 0.037 & 0.000 & 0.189 & 0.047 & 0.000 & 0.212 & 0.132 & 0.000 & 0.338 \\
\hline fraud & 0.091 & 0 & 0.287 & 0.074 & 0.000 & 0.262 & 0.080 & 0.000 & 0.271 & 0.111 & 0.000 & 0.314 \\
\hline \multicolumn{13}{|c|}{ Other audit-related variables } \\
\hline nas & 0.085 & 0.000 & 0.155 & 0.113 & 0.030 & 0.176 & 0.100 & 0.000 & 0.174 & 0.052 & 0.000 & 0.113 \\
\hline ind_spec & 0.061 & 0.000 & 0.239 & 0.142 & 0.000 & 0.350 & 0.016 & 0.000 & 0.127 & 0.027 & 0.000 & 0.161 \\
\hline switch & 0.188 & 0.000 & 0.391 & 0.079 & 0.000 & 0.270 & 0.166 & 0.000 & 0.373 & 0.289 & 0.000 & 0.453 \\
\hline tenure & 2.863 & 2.000 & 2.348 & 3.681 & 3.000 & 2.625 & 3.185 & 2.000 & 2.691 & 2.010 & 2.000 & 1.405 \\
\hline feestoassets & 0.072 & 0.002 & 1.134 & 0.004 & 0.003 & 0.006 & 0.004 & 0.001 & 0.021 & 0.183 & 0.002 & 1.828 \\
\hline lnauditfees & 12.843 & 12.855 & 1.453 & 13.585 & 13.732 & 0.754 & 13.452 & 13.462 & 1.530 & 11.736 & 11.857 & 1.173 \\
\hline Innonafees & 10.882 & 10.834 & 1.958 & 11.543 & 11.609 & 1.470 & 11.741 & 12.043 & 2.034 & 9.434 & 9.275 & 1.554 \\
\hline Intotalfees & 12.973 & 13.057 & 1.497 & 13.748 & 13.857 & 0.743 & 13.621 & 13.694 & 1.554 & 11.808 & 11.941 & 1.209 \\
\hline \multicolumn{13}{|c|}{ Economic and operating characteristics of client firm } \\
\hline lnage & 1.610 & 1.609 & 0.653 & 1.611 & 1.609 & 0.561 & 1.706 & 1.792 & 0.652 & 1.545 & 1.386 & 0.710 \\
\hline lnta & 4.951 & 5.023 & 2.580 & 5.786 & 5.711 & 1.231 & 6.443 & 5.817 & 2.594 & 3.304 & 3.901 & 2.427 \\
\hline roa & -0.168 & 0.053 & 1.266 & 0.032 & 0.057 & 0.225 & -0.010 & 0.053 & 0.538 & -0.430 & 0.047 & 1.891 \\
\hline lev & 0.102 & 0.000 & 0.213 & 0.063 & 0.000 & 0.131 & 0.120 & 0.036 & 0.185 & 0.121 & 0.000 & 0.270 \\
\hline loss & 0.305 & 0.000 & 0.461 & 0.268 & 0.000 & 0.443 & 0.228 & 0.000 & 0.420 & 0.386 & 0.000 & 0.487 \\
\hline
\end{tabular}

This article is protected by copyright. All rights reserved. 


\begin{tabular}{|c|c|c|c|c|c|c|c|c|c|c|c|c|}
\hline cfo & -0.272 & 0.064 & 8.223 & 0.090 & 0.086 & 0.170 & 0.068 & 0.091 & 0.240 & -0.780 & 0.017 & 12.852 \\
\hline fin & 13.491 & 0.197 & 87.584 & 0.240 & 0.168 & 0.342 & 1.146 & 0.172 & 7.636 & 32.073 & 0.329 & 134.792 \\
\hline$m t b$ & 2.006 & 1.162 & 5.553 & 2.530 & 1.506 & 3.701 & 2.095 & 1.310 & 4.821 & 1.538 & 0.749 & 6.993 \\
\hline nevada & 0.191 & 0.000 & 0.394 & 0.026 & 0.000 & 0.160 & 0.146 & 0.000 & 0.354 & 0.350 & 0.000 & 0.477 \\
\hline soe & 0.072 & 0.000 & 0.259 & 0.012 & 0.000 & 0.111 & 0.239 & 0.000 & 0.427 & 0.007 & 0.000 & 0.085 \\
\hline$a d r$ & 0.223 & 0.000 & 0.417 & 0.455 & 0.000 & 0.498 & 0.253 & 0.000 & 0.435 & 0.023 & 0.000 & 0.150 \\
\hline
\end{tabular}

This article is protected by copyright. All rights reserved. 
Table 4: Probability of choosing a small US principal auditor

\begin{tabular}{|c|c|c|c|}
\hline \multicolumn{4}{|c|}{ Dependent variable: aud_us $\times$ aud_small } \\
\hline & Coeff. & Std. err. & $z$ \\
\hline nas & -0.038 & 0.111 & -0.34 \\
\hline ind_spec & 0.210 & 0.215 & 0.98 \\
\hline switch & 0.069 & 0.103 & 0.66 \\
\hline tenure & -0.042 & 0.031 & -1.34 \\
\hline lnage & 0.115 & 0.073 & 1.57 \\
\hline lnta & $-0.474 * * *$ & 0.035 & -13.37 \\
\hline roa & $0.170 * *$ & 0.069 & 2.48 \\
\hline lev $=$ & 0.004 & 0.211 & 0.02 \\
\hline loss & 0.160 & 0.102 & 1.56 \\
\hline cfo & -0.015 & 0.185 & -0.08 \\
\hline fin & 0.000 & 0.001 & -0.41 \\
\hline$m t b$ & -0.014 & 0.009 & -1.52 \\
\hline nevada & $0.555^{* * *}$ & 0.105 & 5.26 \\
\hline soe & 0.077 & 0.382 & 0.20 \\
\hline$a d r$ & $-1.605 * * *$ & 0.217 & -7.41 \\
\hline constant & 0.132 & 0.665 & 0.20 \\
\hline \multirow{4}{*}{\multicolumn{2}{|c|}{$\begin{array}{l}\text { Year fixed effects } \\
\text { Industry fixed effects } \\
\text { Log likelihood } \\
N\end{array}$}} & \multicolumn{2}{|c|}{ Yes } \\
\hline & & \multicolumn{2}{|c|}{ Yes } \\
\hline & & \multicolumn{2}{|c|}{-655.297} \\
\hline & & \multicolumn{2}{|c|}{2,027} \\
\hline
\end{tabular}

$* * *, * *$ and $*$ indicate significance at the $0.01,0.05$ and 0.10 levels (two-tailed), respectively.

Variable definitions are provided in the Appendix.

This table reports results of a probit regression that examines the probability of choosing a small, US auditor (aud_us $\times$ aud_small).

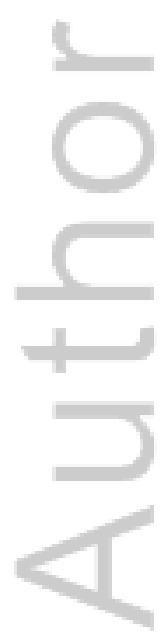

This article is protected by copyright. All rights reserved. 
Table 5: Analysis of discretionary accruals

Panel A: Discretionary accruals as measure of audit quality

\begin{tabular}{|c|c|c|c|c|c|c|c|c|c|c|c|c|}
\hline & \multicolumn{3}{|c|}{ Full sample } & \multicolumn{3}{|c|}{ Full sample using income increasing $d a$} & \multicolumn{3}{|c|}{ Propensity score matched sample } & \multicolumn{3}{|c|}{ Sample with inverse mills ratic } \\
\hline & & (1) & & & (2) & & & (3) & & & (4) & \\
\hline & Coeff. & Std. err. & $t$ & Coeff. & Std. err. & $t$ & Coeff. & Std. err. & $t$ & Coeff. & Std. err. & $t$ \\
\hline aud_us & 0.015 & 0.046 & 0.33 & -0.077 & 0.067 & -1.14 & 0.008 & 0.098 & 0.09 & 0.010 & 0.048 & 0.21 \\
\hline aud_small & $-0.132 * *$ & 0.054 & -2.46 & $-0.193 * *$ & 0.080 & -2.40 & $-0.203 * *$ & 0.101 & -2.01 & $-0.126^{* *}$ & 0.057 & -2.23 \\
\hline aud_us $\times$ aud_small & $0.131 * *$ & 0.062 & 2.12 & $0.296 * * *$ & 0.094 & 3.17 & $0.212 *$ & 0.111 & 1.90 & $0.136 * *$ & 0.064 & 2.11 \\
\hline$a u \bar{d} h k$ & 0.013 & 0.027 & 0.48 & -0.024 & 0.040 & -0.59 & 0.027 & 0.072 & 0.38 & 0.014 & 0.029 & 0.49 \\
\hline aud_midtier & 0.006 & 0.037 & 0.17 & 0.034 & 0.054 & 0.62 & -0.002 & 0.079 & -0.02 & 0.021 & 0.039 & 0.53 \\
\hline nas & -0.002 & 0.023 & -0.08 & -0.031 & 0.034 & -0.91 & -0.045 & 0.042 & -1.08 & -0.008 & 0.024 & -0.34 \\
\hline ind_spec & 0.011 & 0.038 & 0.28 & 0.008 & 0.053 & 0.15 & 0.032 & 0.093 & 0.35 & 0.029 & 0.040 & 0.71 \\
\hline switch & 0.021 & 0.023 & 0.91 & 0.023 & 0.035 & 0.65 & 0.043 & 0.037 & 1.14 & 0.019 & 0.024 & 0.77 \\
\hline tenure & 0.005 & 0.005 & 1.01 & $0.019 * * *$ & 0.007 & 2.72 & 0.014 & 0.014 & 1.05 & 0.001 & 0.006 & 0.14 \\
\hline lnage & 0.000 & 0.016 & -0.02 & $-0.101 * * *$ & 0.024 & -4.27 & 0.013 & 0.025 & 0.51 & 0.001 & 0.017 & 0.04 \\
\hline lnta & $-0.054 * * *$ & 0.007 & -7.87 & $-0.089 * * *$ & 0.011 & -8.18 & $-0.055 * * *$ & 0.013 & -4.34 & $-0.076 * * *$ & 0.015 & -4.90 \\
\hline roa & $0.032 * * *$ & 0.012 & 2.73 & $0.309 * * *$ & 0.033 & 9.50 & $0.032 *$ & 0.017 & 1.89 & $0.043 * * *$ & 0.013 & 3.19 \\
\hline lev & 0.045 & 0.042 & 1.08 & -0.061 & 0.069 & -0.89 & 0.086 & 0.066 & 1.31 & 0.041 & 0.045 & 0.92 \\
\hline loss & -0.019 & 0.020 & -0.95 & $-0.058 *$ & 0.032 & -1.81 & -0.046 & 0.037 & -1.24 & -0.014 & 0.022 & -0.63 \\
\hline$c f o$ & $-0.100 * * *$ & 0.032 & -3.10 & $-0.593 * * *$ & 0.076 & -7.83 & -0.071 & 0.046 & -1.53 & $-0.093 * * *$ & 0.035 & -2.62 \\
\hline fin & $0.001 * * *$ & 0.000 & 4.19 & $0.002 * * *$ & 0.000 & 8.34 & $0.001 * * *$ & 0.000 & 3.22 & $0.001 * * *$ & 0.000 & 4.14 \\
\hline$m t b$ & $0.009 * * *$ & 0.002 & 6.09 & $0.013 * * *$ & 0.003 & 3.87 & $0.012 * * *$ & 0.002 & 5.36 & $0.010 * * *$ & 0.002 & 5.92 \\
\hline nevada & -0.041 & 0.026 & -1.58 & -0.023 & 0.039 & -0.60 & -0.038 & 0.039 & -0.97 & -0.017 & 0.030 & -0.56 \\
\hline soe & $0.128 * *$ & 0.063 & 2.03 & $0.342 * * *$ & 0.100 & 3.42 & $0.379 *$ & 0.197 & 1.92 & 0.094 & 0.071 & 1.33 \\
\hline$a d r$ & -0.016 & 0.025 & -0.64 & -0.057 & 0.036 & -1.57 & 0.049 & 0.072 & 0.68 & -0.116 & 0.073 & -1.58 \\
\hline inverse_mills & & & & & & & & & & 0.078 & 0.05 & 1.55 \\
\hline constant & 0.427 & 0.148 & 2.89 & $0.459 *$ & 0.261 & 1.76 & $0.564 * *$ & 0.233 & 2.41 & $0.338 * *$ & 0.160 & 2.12 \\
\hline Year fixed effects & Yes & & & Yes & & & Yes & & & Yes & & \\
\hline Industry fixed effects & Yes & & & Yes & & & Yes & & & Yes & & \\
\hline Adjusted $R^{2}$ & 0.182 & & & 0.333 & & & 0.182 & & & 0.188 & & \\
\hline$N$ & 2,027 & & & 1,301 & & & 1,036 & & & 1,844 & & \\
\hline
\end{tabular}

$* * *, * *$ and $*$ indicate significance at the $0.01,0.05$ land 0.10 levels (two-tailed), respectively. Variable definitions are provided in the Appendix.

This article is protected by copyright. All rights reserved. 
This table reports results of the effect of auditor location and size on various measures of discretionary accruals. We also report results for a propensity score matched sample, with matching based on propensity of choosing a small auditor located in the US, and a two-stage model controlling for choice of auditor.

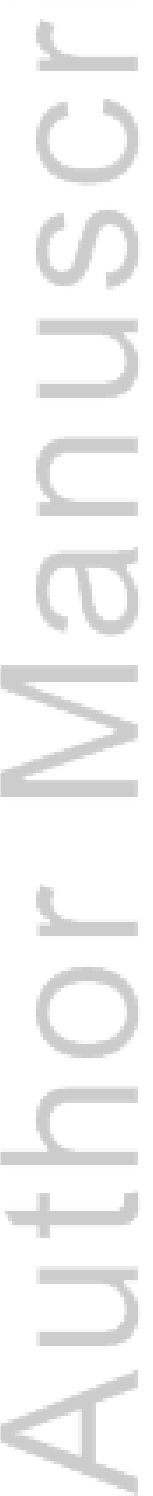

This article is protected by copyright. All rights reserved. 
Panel B: Analysis of discretionary accruals within sub-samples

\begin{tabular}{|c|c|c|c|c|c|c|c|c|c|}
\hline \multirow{3}{*}{$\begin{array}{ll}2+2 \\
+2\end{array}$} & \multicolumn{3}{|c|}{$\begin{array}{c}\text { Small auditors } \\
\text { (US and Hong Kong) }\end{array}$} & \multicolumn{3}{|c|}{$\begin{array}{c}\text { Mid-tier auditors } \\
\text { (Mainland China, US and Hong Kong) }\end{array}$} & \multicolumn{3}{|c|}{$\begin{array}{l}\text { Small US auditors versus } \\
\text { Big } 4 \text { auditors with principal } \\
\text { auditor in mainland China }\end{array}$} \\
\hline & \multicolumn{3}{|c|}{ (1) } & \multicolumn{3}{|c|}{$(2)$} & \multicolumn{3}{|c|}{$(3)$} \\
\hline & Coeff. & Std. err. & $t$ & Coeff. & Std. err. & $t$ & Coeff. & Std. err. & $t$ \\
\hline aud_us & $0.133 * *$ & 0.061 & -2.19 & 0.036 & 0.048 & 0.76 & $0.144 * * *$ & 0.045 & 3.19 \\
\hline aud_hk & & & & -0.027 & 0.040 & -0.68 & & & \\
\hline nas & -0.027 & 0.051 & -0.53 & 0.017 & 0.037 & 0.46 & $-0.057 *$ & 0.033 & -1.72 \\
\hline ind_spec & 0.052 & 0.110 & 0.47 & 0.140 & 0.098 & 1.43 & 0.028 & 0.049 & 0.57 \\
\hline switch & 0.054 & 0.043 & 1.26 & $0.074 * *$ & 0.034 & 2.15 & 0.009 & 0.033 & 0.29 \\
\hline tenure & 0.025 & 0.017 & 1.54 & 0.002 & 0.014 & 0.12 & 0.002 & 0.007 & 0.32 \\
\hline lnage & 0.024 & 0.028 & 0.86 & 0.040 & 0.030 & 1.32 & -0.004 & 0.023 & -0.16 \\
\hline lnta & $-0.051 * * *$ & 0.015 & -3.40 & -0.015 & 0.015 & -0.98 & -0.006 & 0.010 & -0.63 \\
\hline roa & 0.027 & 0.017 & 1.64 & -0.088 & 0.078 & -1.13 & 0.023 & 0.015 & 1.52 \\
\hline lev & 0.108 & 0.077 & 1.41 & -0.059 & 0.086 & -0.69 & 0.053 & 0.058 & 0.91 \\
\hline loss & -0.063 & 0.045 & -1.41 & $-0.088 * *$ & 0.039 & -2.24 & 0.009 & 0.028 & 0.33 \\
\hline$c f o$ & -0.075 & 0.049 & -1.55 & $-0.232 * *$ & 0.111 & -2.09 & $-0.103 * *$ & 0.042 & -2.45 \\
\hline fin & $0.001 * * *$ & 0.000 & 2.87 & $-0.006^{*}$ & 0.004 & -1.79 & $0.001 * * *$ & 0.000 & 4.74 \\
\hline$m t b$ & $0.014 * * *$ & 0.002 & 5.56 & $0.016^{* *}$ & 0.006 & 2.49 & $0.012 * * *$ & 0.002 & 5.76 \\
\hline nevada & -0.028 & 0.045 & -0.63 & 0.047 & 0.033 & 1.41 & -0.037 & 0.039 & -0.93 \\
\hline soe & $0.796 * * *$ & 0.277 & 2.87 & -0.027 & 0.107 & -0.26 & $0.503 * *$ & 0.192 & 2.61 \\
\hline$a d r$ & 0.030 & 0.217 & 0.14 & 0.001 & 0.052 & 0.01 & 0.012 & 0.035 & 0.33 \\
\hline constant & 0.492 & 0.301 & 1.63 & $-0.642 * *$ & 0.430 & -1.49 & 0.198 & 0.235 & 0.84 \\
\hline Year fixed effects & Yes & & & Yes & & & Yes & & \\
\hline Industry fixed effects & Yes & & & Yes & & & Yes & & \\
\hline Adjusted $R^{2}$ & 0.226 & & & 0.358 & & & 0.194 & & \\
\hline$N$ & $786(709+77)$ & & & $300(63+1)$ & & & $1,292(70$ & & \\
\hline
\end{tabular}

$* * *, * *$ and $*$ indicate significance at the $0.01,0.05$ land 0.10 levels (two-tailed), respectively. Variable definitions are provided in the Appendix.

This article is protected by copyright. All rights reserved. 
Models are as per model 1 in Panel A reduced to include only the variable coefficients that can be estimated in the sub-samples. Note that there are no small principal auditors located in mainland China in the sample.

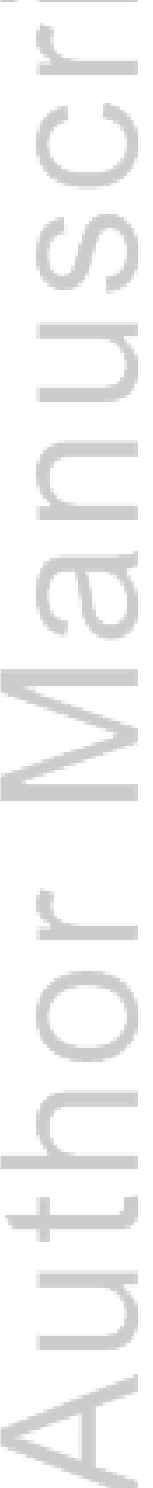

This article is protected by copyright. All rights reserved. 
Table 6: Probability of experiencing a restatement as the measure of audit quality

\begin{tabular}{|c|c|c|c|c|c|c|c|c|c|}
\hline \multirow{3}{*}{2} & \multirow{2}{*}{\multicolumn{3}{|c|}{$\frac{\text { Full sample }}{(1)}$}} & \multirow{2}{*}{\multicolumn{3}{|c|}{$\begin{array}{c}\text { Propensity score matched sample } \\
\text { (2) }\end{array}$}} & \multicolumn{3}{|c|}{ Sample with inverse Mills ratio } \\
\hline & & & & & & & & (3) & \\
\hline & Coeff. & Std. err. & $z$ & Coeff. & Std. err. & $z$ & Coeff. & Std. err. & $z$ \\
\hline aud_us & -0.296 & 0.528 & -0.56 & -0.394 & 0.930 & -0.42 & -0.252 & 0.532 & -0.47 \\
\hline aud_small & 0.488 & 0.656 & 0.74 & -0.156 & 0.908 & -0.17 & 0.279 & 0.667 & 0.42 \\
\hline aud_us $\times$ aud_small & $1.312 *$ & 0.678 & 1.93 & $1.870 *$ & 0.991 & 1.89 & $1.266^{*}$ & 0.680 & 1.86 \\
\hline$a u d \_h k \cap$ & 0.012 & 0.382 & 0.03 & 0.557 & 0.681 & 0.82 & 0.002 & 0.384 & 0.01 \\
\hline aud_midtier & $1.077 * *$ & 0.454 & 2.38 & 0.485 & 0.736 & 0.66 & $0.846^{*}$ & 0.471 & 1.79 \\
\hline nas & $0.976 * * *$ & 0.264 & 3.70 & $0.900 * * *$ & 0.314 & 2.87 & $0.962 * * *$ & 0.267 & 3.60 \\
\hline ind_spec & -1.199 & 0.774 & -1.55 & -1.353 & 1.107 & -1.22 & -1.252 & 0.783 & -1.60 \\
\hline switch & $0.454^{*}$ & 0.235 & 1.93 & 0.266 & 0.286 & 0.93 & 0.346 & 0.241 & 1.44 \\
\hline tenure & $0.107 *$ & 0.061 & 1.74 & 0.118 & 0.102 & 1.16 & $0.121 *$ & 0.071 & 1.69 \\
\hline lnage & -0.037 & 0.167 & -0.22 & -0.017 & 0.192 & -0.09 & -0.048 & 0.169 & -0.28 \\
\hline Inta & 0.039 & 0.089 & 0.45 & 0.129 & 0.110 & 1.18 & 0.304 & 0.219 & 1.39 \\
\hline roa & 0.247 & 0.282 & 0.88 & 0.302 & 0.335 & 0.90 & 0.173 & 0.306 & 0.56 \\
\hline lev & $-2.719 * * *$ & 0.821 & -3.31 & $-2.916^{* * *}$ & 0.943 & -3.09 & $-2.665 * * *$ & 0.853 & -3.12 \\
\hline loss & 0.305 & 0.230 & 1.33 & $0.717 * *$ & 0.284 & 2.53 & 0.260 & 0.241 & 1.08 \\
\hline$c f o$ & -0.732 & 0.553 & -1.32 & -0.832 & 0.618 & -1.35 & -0.405 & 0.610 & -0.66 \\
\hline fin & -0.005 & 0.004 & -1.21 & -0.005 & 0.005 & -1.13 & -0.002 & 0.004 & -0.43 \\
\hline$m t b$ & 0.004 & 0.020 & 0.18 & 0.014 & 0.021 & 0.66 & 0.017 & 0.022 & 0.76 \\
\hline nevada & -0.133 & 0.239 & -0.56 & -0.055 & 0.279 & -0.20 & -0.425 & 0.329 & -1.29 \\
\hline soe & -0.545 & 0.977 & -0.56 & -0.072 & 1.253 & -0.06 & -0.696 & 1.116 & -0.62 \\
\hline$a d r$ & $-0.994 * *$ & 0.432 & -2.30 & $-1.904 *$ & 1.118 & -1.70 & 0.165 & 1.107 & 0.15 \\
\hline inverse_mills & & & & & & & -0.950 & 0.746 & -1.27 \\
\hline constant & $-4.733 * * *$ & 1.190 & -3.98 & $-5.854 * * *$ & 1.601 & -3.66 & $-4.744 * * *$ & 1.189 & -3.99 \\
\hline Year fixed effects & Yes & & & Yes & & & Yes & & \\
\hline Industry fixed effects & Yes & & & Yes & & & Yes & & \\
\hline Log pseudo likelihood & -441.483 & & & -294.102 & & & -423.560 & & \\
\hline Pseudo $R^{2}$ & 0.170 & & & 0.170 & & & 0.170 & & \\
\hline
\end{tabular}

This article is protected by copyright. All rights reserved. 
$* * *, * *$ and $*$ indicate significance at the $0.01,0.05$ and 0.10 levels (two-tailed), respectively. Variable definitions are provided in the Appendix

This table reports the results of the effect of auditor location and size on the probability of restatement (restate) using the full sample. We also match based on propensity score of choosing a small auditor located in the US and the model is re-estimated using the propensity score matched sample.

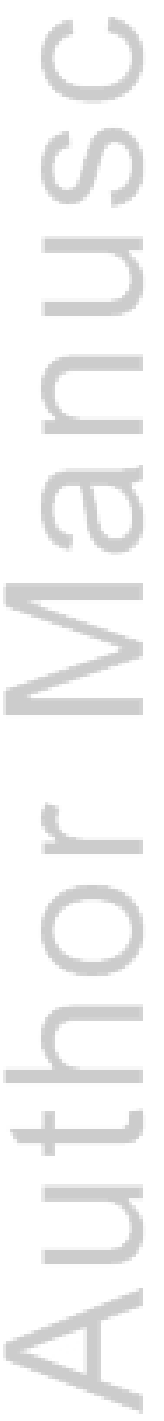

This article is protected by copyright. All rights reserved. 
Table 7: Probability of experiencing a fraud allegation as measure of audit quality

\begin{tabular}{|c|c|c|c|c|c|c|c|c|c|}
\hline \multirow{3}{*}{2} & \multirow{2}{*}{\multicolumn{3}{|c|}{$\frac{\text { Full sample }}{\text { (1) }}$}} & \multirow{2}{*}{\multicolumn{3}{|c|}{$\begin{array}{c}\text { Propensity score matched sample } \\
\text { (2) }\end{array}$}} & \multicolumn{3}{|c|}{ Sample with inverse Mills ratio } \\
\hline & & & & & & & & (3) & \\
\hline & Coeff. & Std. err. & $z$ & Coeff. & Std. err. & $z$ & Coeff. & Std. err. & $z$ \\
\hline aud_us & $1.030 * *$ & 0.447 & 2.30 & $2.431 * *$ & 1.000 & 2.43 & $1.088 * *$ & 0.451 & 2.41 \\
\hline aud_small & $1.311 * *$ & 0.603 & 2.17 & 1.335 & 1.013 & 1.32 & $1.233 *$ & 0.628 & 1.96 \\
\hline aud_us $\times$ aud_small & 0.224 & 0.296 & 0.76 & -0.943 & 1.059 & -0.89 & -0.724 & 0.661 & -1.10 \\
\hline aud_hk & -0.843 & 0.630 & -1.34 & $1.524 * *$ & 0.716 & 2.13 & 0.260 & 0.296 & 0.88 \\
\hline aud_midtier & 0.433 & 0.394 & 1.10 & 0.174 & 0.864 & 0.20 & 0.454 & 0.405 & 1.12 \\
\hline nas & $0.918 * * *$ & 0.254 & 3.61 & $1.322 * * *$ & 0.382 & 3.46 & $0.932 * * *$ & 0.256 & 3.64 \\
\hline ind_spec & 0.134 & 0.385 & 0.35 & -0.160 & 0.831 & -0.19 & 0.195 & 0.430 & 0.45 \\
\hline switch & -0.029 & 0.243 & -0.12 & -0.121 & 0.354 & -0.34 & 0.011 & 0.248 & 0.04 \\
\hline tenure & $-0.175^{* * *}$ & 0.061 & -2.87 & $-0.271 *$ & 0.136 & -1.99 & $-0.190 * * *$ & 0.073 & -2.60 \\
\hline lnage & $0.425 * *$ & 0.190 & 2.23 & $0.986 * * *$ & 0.280 & 3.52 & $0.456^{* *}$ & 0.200 & 2.28 \\
\hline lnta & $0.611 * * *$ & 0.111 & 5.48 & $0.778 * * *$ & 0.186 & 4.19 & 0.468 & 0.387 & 1.21 \\
\hline roa & 0.649 & 0.981 & 0.66 & 1.747 & 1.489 & 1.17 & 0.860 & 1.030 & 0.83 \\
\hline lev & $-1.485^{* *}$ & 0.653 & -2.27 & $-3.158 * * *$ & 1.181 & -2.67 & $-1.748 * *$ & 0.685 & -2.55 \\
\hline loss & -0.153 & 0.308 & -0.50 & 0.063 & 0.503 & 0.13 & -0.113 & 0.336 & -0.34 \\
\hline cfo & 0.202 & 0.783 & 0.26 & 1.473 & 1.208 & 1.22 & 0.058 & 0.792 & 0.07 \\
\hline fin & -0.377 & 0.272 & -1.39 & -0.347 & 0.253 & -1.37 & -0.384 & 0.276 & -1.39 \\
\hline$m t b$ & 0.027 & 0.034 & 0.78 & $0.168 * * *$ & 0.058 & 2.90 & 0.019 & 0.038 & 0.52 \\
\hline nevada & $0.963 * * *$ & 0.263 & 3.66 & $1.181 * * *$ & 0.362 & 3.26 & $1.094 * *$ & 0.455 & 2.41 \\
\hline soe & $-3.882 * * *$ & 1.131 & -3.43 & -1.903 & 1.395 & -1.36 & $-2.132 * *$ & 1.041 & -2.05 \\
\hline$a d r$ & 0.272 & 0.99 & 0.276 & $-1.280^{*}$ & 0.681 & 1.88 & -0.259 & 1.455 & -0.18 \\
\hline inverse_mills & & & & & & & 0.457 & 1.036 & 0.44 \\
\hline constant & $-8.240 * * *$ & 1.176 & -7.01 & $-10.872 * * *$ & 1.920 & -5.66 & $-8.120 * * *$ & 1.306 & -6.22 \\
\hline Year fixed effects & Yes & & & Yes & & & Yes & & \\
\hline Industry fixed & Yes & & & Yes & & & Yes & & \\
\hline Log pseudo likelihood & -460.115 & & & -195.753 & & & -452.774 & & \\
\hline Pseudo $R^{2}$ & 0.203 & & & 0.302 & & & 0.202 & & \\
\hline
\end{tabular}

This article is protected by copyright. All rights reserved. 
$N \quad 1,654 \quad 730 \quad 1,638$

This table reports results of the effect of auditor location and size on the probability of fraud (fraud) using the full sample. We also match based on propensity score of choosing a small auditor located in the US and the model is re-estimated using the propensity score matched sample.

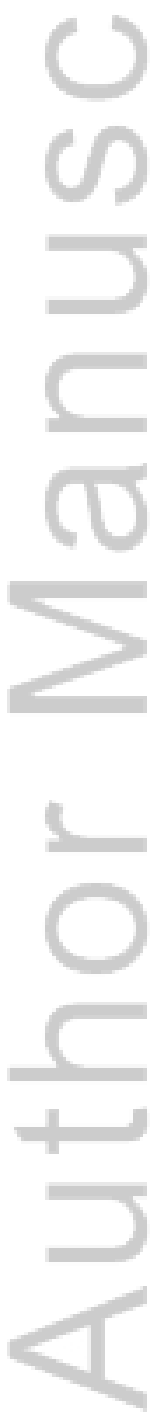

This article is protected by copyright. All rights reserved. 


\section{University Library}

\section{- M M I E E R VA A gateway to Melbourne's research publications}

Minerva Access is the Institutional Repository of The University of Melbourne

Author/s:

Dang, CM;Fargher, N;Lee, G

Title:

Audit Quality for US-listed Chinese Companies

Date:

2017-07-01

Citation:

Dang, C. M., Fargher, N. \& Lee, G. (2017). Audit Quality for US-listed Chinese Companies.

INTERNATIONAL JOURNAL OF AUDITING, 21 (2), pp.150-163. https://doi.org/10.1111/ ijau. 12085.

Persistent Link:

http://hdl.handle.net/11343/292260 